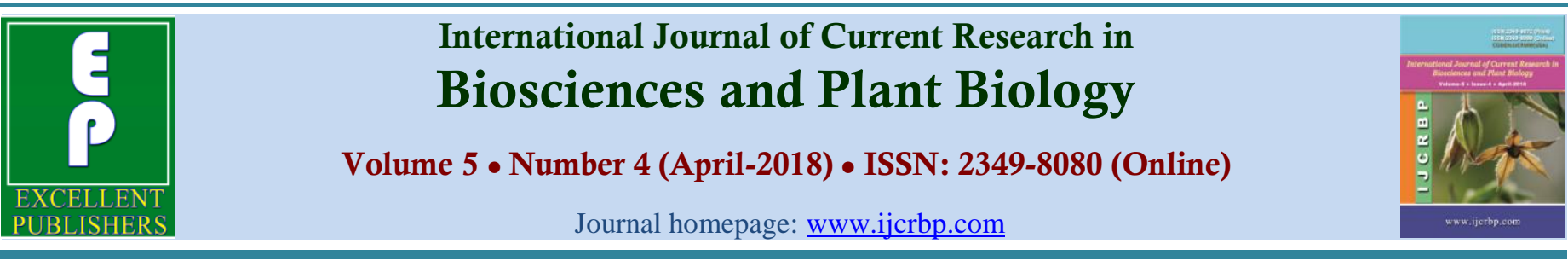

\title{
Characterization, Identification, and Analysis of Plant Growth Regulator (PGR) Conditions to Four Types of Free Clean Maize
}

\author{
Asrijal1* $^{*}$ Elkawakib Syam'un' ${ }^{2}$ Yunus Musa ${ }^{2}$ and Muh. Riadi ${ }^{2}$
}

1Doctoral Program of Agricultural Science, Hasanuddin University, Makassar, South Sulawesi, Indonesia

${ }^{2}$ Agricultural, Faculty of Agrotechnology, Hasanuddin University, Makassar, South Sulawesi, Indonesia

${ }^{*}$ Corresponding author.

\begin{tabular}{|c|c|}
\hline Article Info & ABSTRACT \\
\hline $\begin{array}{l}\text { Date of Acceptance: } \\
25 \text { March } 2018 \\
\text { Date of Publication: } \\
\text { 06 April } 2018\end{array}$ & \multirow{3}{*}{$\begin{array}{l}\text { The high price of chemical fertilizers and residues in the soil, resulting in low } \\
\text { production of food and vegetables, biological fertilizer is believed to be able to improve } \\
\text { and improve the availability of nutrients in the soil by utilizing existing compounds in } \\
\text { plants in the form of PGR. Plants in general have the potential to produce various } \\
\text { compounds, one of which is in the form of "natural PGR". The issue now is that PGR is } \\
\text { naturally environmentally friendly. Eco-friendly agriculture uses a lot of natural PGR } \\
\text { However, natural PGR is still very limited. This study aims to obtain PGR content from } \\
\text { sweet corn, pulut corn, yellow corn, and white corn. The results showed that the } \\
\text { highest content of auxin (IAA) was found in sweet corn PGR of } 27.9303 \text { ppm and the } \\
\text { lowest was yellow corn PGR of } 2.2689 \text { ppm. The highest gibberellin content is found in } \\
\text { sweet corn PGR of } 442.8318 \text { ppm and the lowest is yellow corn PGR of } 74,0705 \text { ppm. } \\
\text { The highest content of cytokines (kinetin) is found in pulut corn PGR of } 45.8963 \text { ppm } \\
\text { and the lowest is yellow corn PGR of } 33.5830 \text { ppm. }\end{array}$} \\
\hline Keywords & \\
\hline $\begin{array}{l}\text { Auxin } \\
\text { Cytokines } \\
\text { Gibberellin } \\
\text { Maize } \\
\text { Plant growth regulator }\end{array}$ & \\
\hline
\end{tabular}

\section{Introduction}

One role of plant hormones is to influence flowering initiation by regulating the balance between carbohydrates and nitrogen ( $\mathrm{C} / \mathrm{N}$ ratio). Excess supply of nutrients (carbohydrates) in plants will stimulate the flowering. Arika et al. (2009) states that gibberellin is able to increase the $\mathrm{C} / \mathrm{N}$ ratio. The higher the $\mathrm{C} / \mathrm{N}$ ratio, the plant will undergo a transition from the vegetative to the reproductive. This leads to faster flower initiation time.Giberelin is able to accelerate flowering of plants through the activation of flower meristem genes by producing proteins that will induce the expression of flowering organ genes (such as corolla, kalix, stamen, and pistillum) (Arika et al., 2009). Auxin is one of the plant hormones that can regulate many physiological processes, such as growth, cleavage and cell differentiation and protein synthesis (Darnell et al., 1986).

Increased cytokinin concentration in leaves is one of the important hormonal phenomena for flower induction. Ryugo (1990) states that the application 
of cytokinin on the surface of the cut thread can increase the percentage of the flower buds. Based on this suspected ZPT has an important role in spurring the emergence of flowers, especially hermaphrodites on Jatropha curcas.Applications of growth regulators in modern agriculture include securing yields, increasing size and improving product quality (e.g. in seedless watermelon technology), or uniform flowering time (e.g. in ethylene applications for uniform flowering of seasonal fruits) (Supriyanto and Kaka, 2011). So far known to a number of classes of substances considered as phytohormones, namely auxin, cytokinin, giberilin or gibberellic acid (GA), ethylene, abscisic acid (ABA), jasmonic acid, steroids (brasinosteroids), salicylates and polyamines (Rochimi, 2008).

The growth regulator is a non-nutrient organic compound which in low concentration can encourage, inhibit or qualitatively change the growth and development of plants (Widyastuti and Tjokrokusumo, 2001 in Amraini and Sugiyanta, 2008). PGR applications in plants can influence the transport of assimilates, complementary senensen and cell enlargement (Wattimena, 1988 in Amraini and Sugiyanta, 2008). The effect of PGR application on a plant will be obvious if the condition is healthy, the nutrients are met and.Auxins play a role in growth to spur the process of cell lengthening (Zhao, 2008, Zhao, 2010; Bajguz and Piotrowska, 2009) the formation of lateral roots and root fibers causing the absorption of air and minerals can run optimally. Cytokinin is a hormone that plays a role in cell division (cytokinesis) (Zhao, 2008; Zhao, 2010; Kyozuka, 2007; Bajguz and Piotrowska, 2009).

The function of cytokines is to stimulate the formation of roots and stems and the formation of root branches by inhibiting apical dominance, regulating the growth of leaves and shoots, and inhibiting the aging process by stimulating the process as well as transporting mineral and amino acid salts to the leaves (Taiz and Zeiger, 2002; Kyozuka, 2007; Raffaele, 2008; Bajguz and Piotrowska, 2009). According to Karadeniz et al.,
(2006); Samse and Tiurmaida, (2006) Giberelin function in the process of seed formation, which stimulates the formation of pollen (pollen), enlarge the size of the fruit, stimulate the formation of flowers, and end the dormancy period. Giberelin with low concentrations does not stimulate root formation, but at high concentrations will stimulate root formation (Jauhar et al., 2013).

Growth and development of plants progresses continuously throughout the life cycle, depending on the availability of meristems, assimilation products, hormones and other growth substances and a supportive environment (Gardner et al., 1991). In this regard various efforts have been made in the effort to increase the growth and production of plants, both the method of cultivation, as well as the addition of various substances of growth. One is the use of growth hormones to increase plant growth and production. Plants naturally already contain growth hormone called endogenous hormone. However, this hormone is less optimum affect the process of vegetative growth and reproductive plants. The addition of Plant Growing Regulators (PGR) is often done to optimize vegetative and reproductive growth of crops, eg gibberellin (GA) capable of accelerating growth and flowering (Abidin 1985 in Siti Komariyah et al., 2012).

Plants in general have the potential to produce various compounds, one of which is in the form of "Hormone". The current issue is the environmentally friendly hormone (Jauhar et al., 2013). Eco-friendly agriculture uses a lot of natural hormones. However, natural hormones are still very limited. This study aims to obtain the content of the Plant Growing Regulatory (PGR) of various types of corn free plants.

\section{Materials and Methods}

\section{Place and time}

The experiment was conducted at Field Trial of STIP Prima Sengkang, Laboratory of STIP Prima Sengkang, and Laboratory of SUA of Service 
Business and Industry, Biofuture. Dep. Biology, FMIPA-IPB. Its implementation time starts from June 2016 until April 2017.

\section{Materials and tools}

The materials used in this study were the seeds of sweet corn crop varieties SD3-IPB, corn pulut varieties Pulut Uri, yellow varieties Lamuru maize, and white varieties Srikandi White-1 variety, aquades, molasses, EM4, Urea fertilizer, NPK Mutiara fertilizer, and Organic Fertilizer (fertilizer given according to recommendation of KATAM, BPPP, 2016). The tools used were blender, plastic bucket with size 2 cover, electric scales, strainer, 10-liter jerry can, rubber binder, $1 \mathrm{~m}$ clear plastic, plastic mouthpiece / funnel, separating funnel, aluminum foil, evaporator, spectrophotometer, roll meter, hoe, hand tractor mini (making bed), semi automatic knapsack sprayer, Dinamao water pump, Electricity PLN, Sprinkler, tablespoon / tea, measuring cups (size 2 liters), Erlenmeyer flask (2 liters), sickles, machetes, hoes, labels, cameras, and stationery. The data analysis used was descriptive statistic analysis based on data of analysis result done in Laboratory of SUA of Business Service and Industry, Biofuture, Dep. Biology, FMIPA-IPB.

\section{Implementation stages}

The first stage was the preparation of the land covering the processing, making the beds, and planting four types of corn, namely sweet corn varieties SD3-IPB, corn pulut Ury varieties, yellow varieties Lamuru corn, and white varieties Srikandi White-1 variety. The second stage was to make PGR extract using sweet corn, corn, yellow corn, and white corn (Diptan, 2016; Heru, 2012; Protected, 2015; Herusidik, 2014, Ulfa, 2014). The place of preparation of PGR extract was at STIP Laboratory of Puangrimaggalatung Sengkang, conducted on the 8th of 2016. Materials used include: $3 \mathrm{~kg}$ of sweet corn seeds, $3 \mathrm{~kg}$ of corn pulut seeds, $3 \mathrm{~kg}$ of seeds of yellow corn, $3 \mathrm{~kg}$ of maize seeds white, 15 liters of aquades, 3 liters of molasses, 1.5 liters of EM4. And the tools used are: blender, plastic bucket which has size 2 cover (15-
20 liters of water), electric scales, strainer, 15-20 liters jerry can, rubber fastener, $1 \mathrm{~m}$ clear plastic, plastic mouthpiece / funnel, Erlenmeyer Pump (1 liter size), tablespoons / teas, labels, cameras, and stationery.

The process of making PGR extract was to take each $3 \mathrm{~kg}$ of corn seeds in the milk ripe seed phase which was marked when pressed with nails would release a white liquid like milk, for sweet corn (estimated age 65-70 days after planting), yellow maize (estimated age 60- 65 days after planting), corn pulut (estimated age 60-65 days after planting), and white maize (estimated age 65-70 days after planting) (USDA, 2016; Musa et al., 2014). Corn seeds that have been taken in the Field of Experiments STIP Puangrimaggalatung Sengkang, Wajo Regency and then put each of the PGR extract ingredients into a blender (four blenders), then each blender was inserted into a bucket (four buckets) containing 60 liters of aquades $(4 \times 15$ liters of aquadest), 12 liters of molasses $(4 \times 3$ liters of sugar cane), 6 liters EM4 $(4 \times 1.5$ liters EM4), then the mixture was stirred until smooth, then the plastic bucket was covered and tied with rubber (plastic loosened, so the lid does not break during the fermentation process) stored and placed in a shade / dark (not subject to sunlight), left for 15 days (Ulfa, 2014).

Every morning the lid was opened and the material was stirred, then closed again, filtered the materials to separate the liquid zpt and the dregs, then stored in a sealed container. PGR was ready for use in the form of "Biang" as much as 15 liters (Diptan, 2016; Heru, 2012; Protected, 2015; Herusidik, 2014) (Fig. $1)$. The third stage was the finished PGR then taken each $250 \mathrm{ml}$ to be analyzed for its contents in the Laboratory of SUA Business Services and Industry, Biofuture, Dep. Biology, FMIPA-IPB. The analysis process began with a 24-hour extract separation process wrapped in aluminum foil. Next it was taken into the evaporator process. The analysis results were seen on the UV-VIS Spectrophotometric display. The method of PGR analysis adopted was from Unyayar et al. (1996). 


\section{Results and discussion}

The results of the analysis that has been carried out in the Laboratory SUA Business Services and Industry, Biofuture. Dep. Biology, FMIPA-IPB Bogor to four types of PGR from free-ranged maize plants, showed different results in terms of PGR content possessed by all four free-radical maize plants. The results of PGR content analysis of the four corn free crops as follows (Fig. 2).

PGR from sweet corn has auxin content in the form of IAA (27.9303 ppm); gibberellin (442.8318 ppm); and cytokines in the form of Kinetin (34.5724 ppm). PGR from pulut corn has auxin content in the form of IAA (8.9201 ppm); Giberelin (140.9394 ppm); and cytokines in the form of kinetin (45.8963 ppm). PGR from yellow corn has auxin content in the form of IAA (2.2689 ppm); Gibberellin (74.0705 ppm); and cytokines in the form of kinetin
(33.5830 ppm). PGR from white corn has auxin content in the form of IAA (18.3866 ppm); Giberelin (398.9600 ppm); and cytokines in the form of kinetin (41.1185 ppm).

Based on the results of the analysis of PGR content of four types of corn-free crops turned out all have different auksin (IAA), gibberellin, and cytokinin (kinetin) contents.The highest content of auxin (IAA) was found in sweet corn PGR of 27.9303 ppm and the lowest was yellow corn PGR of 2.2689 ppm.Auxins play a role in growth to spur the process of cell lengthening (Zhao, 2008; Zhao, 2010; Bajguz and Piotrowska, 2009) the formation of lateral roots and root fibers causes the absorption of water and minerals to run optimally. Auxin is one of the plant hormones that can regulate many physiological processes, such as growth, cleavage and cell differentiation and protein synthesis (Darnell et al., 1986).

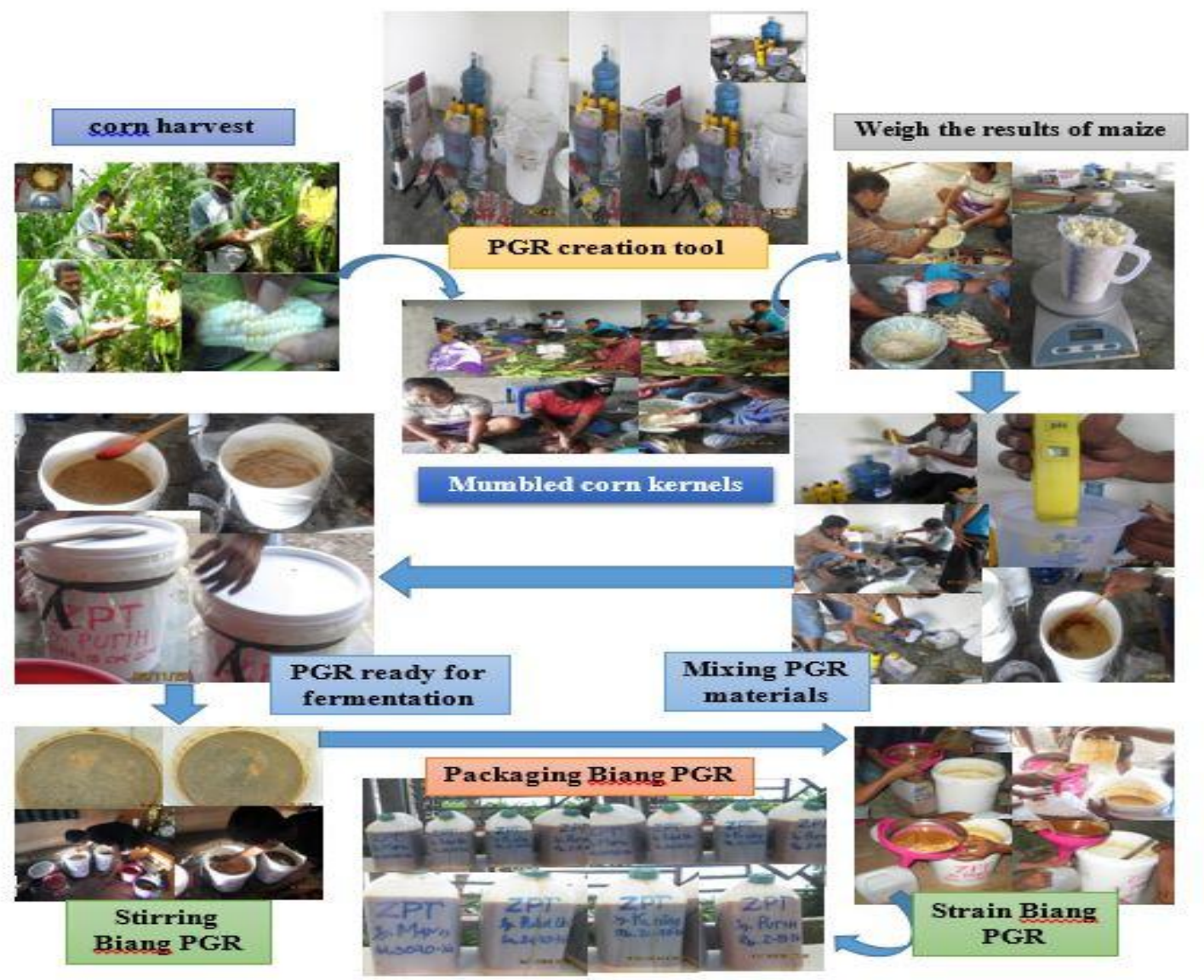

Fig. 1: Activity of the second stage of PGR making process to move the PGR into the jeregen, and PGR's packaged and ready for use. 


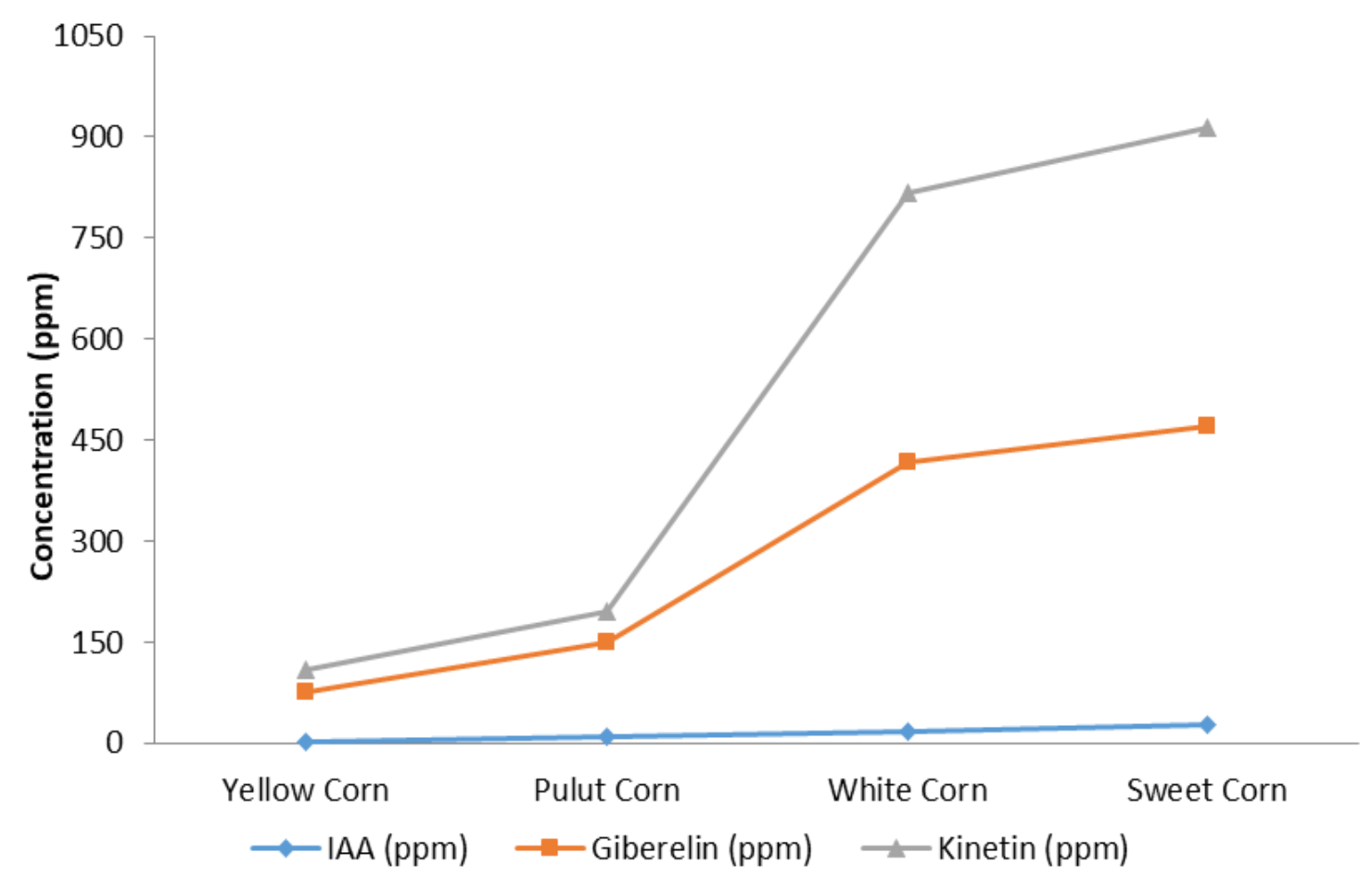

Fig. 2: Results of PGR content analysis of the four types of free-ranged maize at the Laboratory of SUA Business Services and Industry, Biofuture, Dept. of Biology, FMIPA-IPB.

Table 1. Comparative data of ZPT content analysis of results with the method of Unyayar et al. (1996).

\begin{tabular}{lllll}
\hline \multirow{2}{*}{ Material } & PGR (ppm) & & & \multirow{2}{*}{ Source } \\
\cline { 2 - 4 } & IAA & GA3 & Kinetin & Siti Komariyah $(2012)$ \\
\hline Jatropha Leaves & 5.47 & 5.52 & 0.001 & Ulfa (2014) \\
Sweet Corn Seeds & 1.67 & 41.23 & 53.94 & Present study \\
White Corn Seeds & 18.39 & 398.97 & 41.12 & Present study \\
Sweet Corn Seeds & 27.93 & 442.83 & 34.57 & \\
\hline
\end{tabular}

The highest gibberellin content is found in sweet corn PGR of $442.8318 \mathrm{ppm}$ and the lowest is yellow corn PGR of 74.0705 ppm.

Giberelin is able to accelerate flowering of plants through the activation of flower meristem genes by producing proteins that will induce the expression of flowering organ genes (such as corolla, kalix, stamen, and pistillum) (Arika et al., 2009).

The highest content of cytokines (kinetin) is found in PGR of corn pulut $45.8963 \mathrm{ppm}$ and the lowest is yellow corn PGR of $33.5830 \mathrm{ppm}$. Cytokines are hormones that play a role in cell division (cytokinesis) (Zhao, 2008; Zhao, 2010; Kyozuka, 2007; Bajguz and Piotrowska, 2009).
Kinetin is a PGR that promotes cleavage (cytokinesis), commonly present in root ends and meristem areas that undergo rapid cell division, as well as in developing regions (Prawitasari et al., 2002). The results of Siti Komariyah (2012), that spraying auksin and giberelin against andromonoecious plants can increase endogenous auxin and gibberellin content. And spraying kinetin on the jatropha and the cromicoecious can increase the number of inflorescence branches of flowers.

The results of Ulfa (2014), it can be said that the author's PGR content can be generally much higher than the two researchers above, so it is possible to apply to plants for can produce optimal production (Table 1). 
Based on the results and discussion, it can be concluded as follows (a). The highest auxin (IAA) and gibberellin content are found in Sweet Corn PGR, (b). The highest content of cytokines (kinetin) is found in corn pulp PGR, and (c). The lowest PGR content found in yellow corn PGR.

\section{Conflict of interest statement}

Authors declare that they have no conflict of interest.

\section{Acknowledgments}

On this occasion the authors thank the Elkawakib Syam'un, Yunus Musa, and Muh. Riadi, as the promoter team. And also to Graduate School Universihasanuddin Makassar.

\section{References}

Amraini, D., Sugiyanta, 2008. Influence of Fipronil and Metiram Growth Controlling Regents on Growth, Results and Quality of Paddy Rice (Oryza sativa L.). Essay. Prodi Agronomi Fak.Pertanian, IPB.

Arika, K.A., Hastuti, E.D., Setiari, N., 2009. Growth and flowering of Jatropha curcas after spraying GA3 with different concentrations. J. Sci. Technol. Res. 10(1), 18-29.

Bajguz, A., Piotrowska, A., 2009. Conjugates of Auxin and cytokinin. Phytochemistry. 70(8), 957-969.

BPPP-Kemenpan, 2016. KATAM Integrated Modern-Version 24. Kec. Tempe, Kab. Wajo, Prov. South Sulawesi. MK. April-September 2016. Retrieved date, May 15, 2016. At 23:15.

BPS - Statistics Indonesia, 2015. Indonesian

Statistical (Statistical Yearbook of Indonesian, 2015). Publication Number: 03220.1509. BPS Catalog: 1101001. Number of Pages: xxxviii+670pages. ISSN: 0126-2912.

BSK - Book of Consumer Statistics, 2015. Food Consumption Statistics 2015. Center for Agricultural Information Systems and Data, Secretariat General, Ministry of Agriculture 2015. Homepage: http://pusdatin.setjen. pertanian.go.id

Darnell, J., Lodish, H., Baltimore, H., 1986. Molecular Cell Biology. Scientific American Books, Inc. New York.

Diptan, 2016. IKA "PGPR": Plant Growth Promoting Rhizobacteria. Biotech Agencies Laboratory UPTD BPTPH Sul-Sel. Dinas Pertanian (Diptan) of Food Crops and Horticulture of South Sulawesi Province.

Gardner, F.P., Pearce, R. B., Mitchell, R. L., 1991. Crop Culture Physiology. Translator Herawati Susilo and Companion Subiyanto. First Printing. Penerbit Universitas Indonesia Press, Jakarta.

Heru, P., 2012. Make PGPR (Plant Growth Promoting Rhizobakteri). Suka Makmur Farmer Group. Retrieved April 20, 2016, at https: // groups of the mesmama. wordpress.com/

Herusidik, 2015. How to Make Plant Hormones

Retrieved on May 22, 2016, at 12:26. At https://kebunmusangking.wordpress.com/

Jauhar, Aritonang, I., Kuswardani, I., 2013. Hormone Agribusiness. Organic Agriculture Clinic - Celestial Clinic. Garut regency, West Java, Indonesia.

Karadeniz, S., Topeuoglu, F., Inan, S., 2006. Auxin, gibberellin, cytokinin and abscisic acid production in some bacteria. World $\mathrm{J}$. Microbiol. Biotechnol. 22, 1061-1064.

Kementan (Ministry of Agriculture), 2013. Description of the Superior Varieties of Maize. Edition 2013. Center for Food Crops Research and Development, Agency for Agricultural Research and Development, Ministry of Agriculture, Maros.

Kyozuka, J., 2007. Control of shoot and root meristem function by cytokinin. Curr. Opin. Plant Biol. 11, 16-22.

Lindung, 2015. Technology for the Application of Bacteria for the Growth of Plant Growth (PGPR) and Growing Regulator (ZPT). Widyaiswara BPP Jambi.

Musa, Y., Dariati, T., Cri Wahyuni, B.Y., 2014. Increased Productivity of Dry and Copyed Land through Assembly of Tolerant Drought Corn Genotype and Salinity with Molecular Detection. Excellence Grant of Higher 
Education. LP2M Unhas, Makassar.

Prawitasari, T., Guhardja, E., Darusman, L.K., Harran, S., Poerwanto, R., 2002. The development of reproductive meristem structure in flowering process of litchi. Biol. 9(4), 119-124.

Raffaele, D. I., Linhares, F. S., Sabatini, S., 2008. Emerging role of cytokinin as a regulator of cellular differentiation. Curr. Opin. Plant Biol. $11,16-22$.

Rochimi, D.K., 2008. Production of Biti Seed (Vitex cofassus Reinw. Ex Blume) through Vegetative Breeding. Skripsi. Bogor: Faculty of Forestry Bogor Agricultural University.

Ryugo, K., 1990. Flowering and fruit set in temperate fruit trees. di dalam: Proceedings of the Internasional Seminar "Off Season Production of Horticultural Crops ". Taipei, 27 Nov-3 Des 1989.

Salisbury, F.B., Ross, C.W., 1995. Plant Physiology Volume 3. Diah RL, Sumaryono, translator. Bandung: ITB Press. Translation of Plant Physiology.

Samse, P., Tiurmaida, N., 2006. The effect of GA3 and coconut water on the growth of orchid plant planlet (Dendrobium sp.) in vitro. J. Commun. Res. 18(2).

Siti Komariyah, Triadiati, Wahyuni, W.T., 2012. Leaf Regrower Content and Inflorescent Flower Pattern at (Jatropha curcas L.) Andromonoecious. Essay. Department of
Biology, Faculty of Mathematics and Natural Sciences, IPB.

Supriyanto, Prakasa, K. E., 2011. Influence of rootone-F growth regrowing agent on growth of cuttings Duolanga mollucana Blume. J. Trop. Silvicult. 3, 59-65.

Taiz, L., Zeiger, E., 2002. Plant Physiology. 3rd Edn. Sinauer Associates. ISBN: 0878938230. Doi:10.1093/aob/mcg079

Ulfa, F., 2014. The Role of Plant Extract As a Growing Regulator in Spurring Production of Mini Potato Bulbs (Solanum tuberosum L.) on Aeroponic Cultivation System. Dissertation. Prod. Agricultural Science. Graduate program. Unhas, Makassar.

Unyayar, S., Topcuoglu, S.F., Unyayar, A., 1996. A modified method for extraction and identification of indole-3- acetic acid (IAA), giberelin acid (GA3), abcisic acid (ABA) and zeatin produced by Phanerochaete chrysosporium ME446. Bulg. J. Plant Physiol. 22(3-4), 105-110.

USDA, 2016. Detailed List of Sweet Corn Nutrition. United States of America.

Zhao, Y., 2008. The role of local biosynthesis of auxin and cytokinin in plant development. Curr. Opin. Plant Biol. 11, 16-22.

Zhao, Y., 2010. Auxin biosynthesis and its role in plant development. Annu. Rev. Plant Biol. 61, 49-64.

\section{How to cite this article:}

Asrijal, Syam'un, E., Musa, Y., Riadi, M., 2018. Characterization, identification, and analysis of plant growth regulator (PGR) conditions to four types of free clean maize. Int. J. Curr. Res. Biosci. Plant Biol. 5(4), 17-23. doi: https://doi.org/10.20546/ijcrbp.2018.504.003 